\title{
Tokyo 1999 and Beyond
}

\author{
By Toh, Hai Leong
}

Fall 1999 Issue of KINEMA

\section{VIGOROUS JAPAN: TOKYO 1999 AND BEYOND}

This year, several new films by young and energetic Japanese directors stood out at the Tokyo Festival (30 October - 7 November 1999), an 11-day event attended by almost 120,000 festival-goers. In his opening address (graced by Luc Besson's Joan of Arc) the Tokyo Governor Shintaro Ishihara told the audience that "for the past few years, Japanese cinema has lost its vitality, but I hope this situation will be reversed from this film festival." Ishihara caused a stir when he veered from his prepared speech to suggest a change of festival location from outside the "hectic and crowded" Shibuya commercial district "to somewhere nicer, where there is more greenery and better facilities available." True enough but the reality is that most major film festivals, whether in Hong Kong, Pusan, Singapore, New York, or elsewhere, are held in large urban centres with the necessary infrastructure to keep them going.

Already in its $12^{\text {th }}$ edition, the TIFF boasted a number of sections: The Competition section, Special Screenings (world masterpieces), Cinema Prism (homage to film artists focussing on Asian productions), Nippon Cinema Masters (Japanese masterpieces), the Tokyo Film Creators' Forum which included a Project Market to enable young filmmakers to get funding for their new works; Nippon Cinema Now (introducing new Japanese films) and the International Visual Image Symposium (discussion and screening of mostly anime films). Also featured were sponsored events such as the QFront Tokyo International Fantastic Film Festival '99, the Kanebo International Women's Film Week (with a homage to Mabel Cheung, Hong Kong's premier New Wave director) and the Cinema Prism Video Programme (which explored the boundaries of video).

The Competition Section drew 457 entries from 52 countries. Tokyo's International Jury, chaired by the Czech-born British director Karel Reisz (The French Lieutenant's Woman), included Philippine director Marilou Diaz-Abaya (Milagros and Navel of the Sea), Danish producer Peter Aalbak Jensen (Dancing in the Dark), Spanish writer-director Julio Medem (Vacas) and Japanese actress Keiko Matsuzaka (Dr. Akagi, Sting of Death). This year, both the Grand Prize and the Gold Prize for Young Directors with its 10 million Yen (USD 94,000) was awarded to a protege of the world-famous Taiwanese director Hou Hsiao-hsien, the 38-year-old Taiwanese director Chang Tso-chi, for his engaging film Darkness and Light, about a 17-year-old Taipei University co-ed and her relationship with a mentally handicapped brother, her blind father and a doomed underworld man.

The competition was a keenly fought one, with director Chang having to ride over powerful contenders like Satoshi Iseka's murder thriller The Frame, Korean Park Chong-won's bizarre and violent Rainbow Trout, the tender and sad Thai ghost story Nang Nak by Nonzee Nimibutr and about a dozen of others.

Outside the competition, homage was paid to several directors - the Israeli Amos Gitai (his film Sacred opened the Cinema Prism), the legendary Ukrainian Alexander Dovzhenko (Earth), the French master Robert Bresson whose students can compare the performance of Milla Jovovich in the current version of Joan d'Arc with that of the great Bresson actress Florence Carrez of his Trial of Joan d'Arc (1962, Special Jury Prize, Cannes). There was also a nod in the direction of the unjustly neglected veteran Taiwanese director Son Tswen-show, along with the scholarly Li Hsing, the late Pui Jing-rui and King Hu who are now hailed as predecessors to the 1980s Taiwanese New Wave. In his notable debut, Son Tswen-show introduced to Chinese film audiences the celebrated Brigitte Lin Ching Hsia in Outside the Window (1972). Abbas Kiarostami's Venice 1999 Grand Special Jury Prize winner The Wind Will Carry Us closed the Prism section. There were also new discoveries, especially the Indian (Kerala) director Murali Nair with his film Throne of Death, the winner of this year's Cannes Caméra d'or. Thai veteran director Manop Udomdej (1) presented his 1999 latest action film Beyond Forgivin', a kind of "Thai-noir" which was clearly above the average triad-revenge film, rivalling if not surpassing Hollywood and Hong Kong's "film noir" about crimes committed by professional hitmen. Not to be forgotten was 1964 samurai classic Assassination by the Japanese veteran director Masahiro Shinoda, whose 1964 film Assassination (Ansatsu) was shown alongside 
Kon Ichikawa's Her Brother (1960) and Nagisa Oshima's innovative Cruel Story of Youth (1960) in the Nippon Cinema Masters category. Like Akira Kurosawa's Yojimbo, Assassination, set in the Tokugawa era of mid-19th century, is about a ronin who gets caught between the opposing forces of the imperial loyalists and the shogunate supporters, and who must employ his wits and cunning to survive.

Surprisingly, one of the strengths of the Tokyo Festival is its Secretariat, with its video projection booths, its collection of videocassettes with recent films which are available to festival guests and critics covering the festival in their newspapers, magazines and journals.

\section{Creative Ferment}

Among the recent Japanese film productions of 1998 and 1999, there are several which will almost certainly make a name for Japan despite the fact that the country's film critics have been decrying the dismal state of Japanese cinema and have been voicing concern that no major directors of the status of an Akira Kurosawa, Keisuke Kinoshita, Nagisa Oshima, Kenji Mizoguchi, Yasujiro Ozu, Masaki Kobayashi or Masahiro Shinoda have yet surfaced.

Leading the new group of young filmmakers is Kiyoshi Kurosawa who has garnered international acclaim. His latest film, Charisma, was shown at the Directors' Fortnight at Cannes this year, Licenced to Live (Ningen gokaku) at the Berlin festival and Grand Illusion (Oinaru genei) at the Venice festival. Not to be left out is the older director and actor Takeshi Kitano who won Venice's Golden Lion in 1998 for his Fireworks (Hana-bi), and who competed there this year with Kikujiro. Before becoming a film director, Kitano had established a career as a television and film actor, making his mark in the 1982 Nagisa Oshima film Merry Christmas, Mr. Lawrence. His striking debut, Violent Cop, made more than a decade ago, paid homage to Kubrick's Clockwork Orange with the scene of a group of schoolboys savagely beating a helpless vagrant.

Kiyoshi Kurosawa, a generation younger and not a film school graduate, has worked in the Super-8 format since his school days. He has been mostly producing films for video release. In two years or so, he has completed almost half a dozen films, including Cure, Licence to Live, Barren Illusions and Charisma, catapulting from virtual obscurity to becoming a famous and celebrated auteur. His body of works was introduced last April at the Hong Kong Film Festival and his Charisma, an existential-ecological film about a peculiar tree which supposedly exudes poison from its roots, became the most acclaimed and lauded among film critics there.

Ekiben, literally "box lunch," (a slang expression for the standing sex position) is a delightful, introspective documentary about a porn director who dreams of becoming a respected feature film-maker. A recreation of a real-life event, it incorporates interviews with the director Shungo Kaji (as himself), as a "pink film" director. This is a kind of confessional cinéma-vérité with charm and wit, and truly with "intellectual balls"!

Toshiyuki Morioke's Requiem of Darkness is set predominantly in a dinghy theatre. The film's cast of misfits include an ex-yakuza member called Isao, his devoted sister Suchiko, who is lusted after by a doctor, a meek food executive Tawa, the theatre owner's physically abused mistress Erika, and his daughter, Mei, who craves serious art films and posters. Both Ekiben and Requiem of Darkness pay homage to the directors and their works which have influenced them (Kurosawa's Drunken Angel, Fellini's La strada), betraying the fascination these masterful classics hold for the young filmmakers.

A new trend in Japanese film production is the "cross-cultural" film with funding coming from foreign companies to make a "mixed" film, such as Tashiro Hirotaka's Mr. P's Dancing Sushi Bar (1997), starring the legendary Nancy Kwan (World of Suzie Wong) and Frank McRae. In an understated performance, Kwan plays Mitsuko, a clerk at a T-shirt shop on the Venice Beach, California. McRae is Bruce, an AfricanAmerican sushi-chef who marries her and then opens his own sushi bar. Director Tashiro managed to charm viewers with his heart-warming drama of a middle-aged Japanese woman who, at the heart of success, feels as "empty inside" as her husband feels haunted by his Vietnam past.

If the Ian Kerkhof's hardcore and sex-soaked Shabondama Elegy (Dutch-Japanese co-production, 1999) is considered "Japanese", then it is due to the intense acting of former porn actress Mia Hoshino as Keiko, the lover of a Dutch convict Jack (Thom Hoffman). Keiko is a victim of incestuous rape by her father which has 
turned her into a calculating, hard-porn actress, specialising in kinky customised sex.

Of lesser sexual obsession is Isao Morimoto's The First Timers, a bittersweet love story of a young "foreign student" of Japanese Literature and a blind Japanese girl. The film is based on Swiss journalist David Zoppeti's novel of the same name, in which he recounts his experience as student in Kyoto. The First Timers marks Morimoto's brilliant debut about cross-cultural love.

It appears that the future of the Japanese cinema will include an utilisation of digital video technology as in the case of the Shabondama Elegy, which will pave the way for more filmmakers to mix traditional and new technologies. It is also likely to continue to see a blending of acting talents from Japan and elsewhere, thus lifting the typically insular Japanese film into the arena of crossing borders and becoming "international," as in Mr. P's Dancing Sushi Bar. These developments, and the promise exhibited by a younger generation of filmmakers, herald the hope that the New Japanese cinema will dawn sooner than expected.

\section{Notes}

1. Information on the remarkable Thai director Manop Udomdej (1955) is scarce in the West, although he has been making films already since 1981; his first (16mm) feature was On the Fringe of Society (Prachachon nok). In 1985, Udomdej started making films for television; he also made an AIDS awareness short, Thailand's first. Udomdej's other films are The Accusation (1985), Once Is More Than Enough (1987), The Dumb Die Fast, The Smart Die Slow (1991), the short Just Understanding (1992), and Beyond Forgivin' (1999).

\section{References}

\section{AWARDS}

Tokyo Grand Prize - the Governor of Tokyo Award: Heian zhi guang (Darkness and Light) by Chang Tso-chi. The Special Jury Prize: Rainbow Trout by Park Chong-won

Tokyo Gold Prize: Heian zhi guang (Darkness and Light) by Chang Tso-chi.

Best Director: Martha Fiennes, (Onegin, UK)

Best Actress: Maria Galiana (Alone by Benito Zambrano)

Best Actor: Carlos Alvarez-Novoa (Alone by Benito Zambrano)

\section{Author Information}

TOH Hai Leong is a Singapore-based freelance film critic and filmmaker (Zombie Dogs, 2005) who writes for independent film publications such as Screen International and World Paper. He has covered the Hong Kong International Film Festival since 1985 and specializes in the cinemas of Hong Kong, Taiwan, China, Korea and Japan. 